\title{
P177: Community-based learning: medical parasitology in pre-clinical year, Suranaree University of Technology, Thailand
}

\author{
N Kaewpitoon ${ }^{1 *}$, SJ Kaewpitoon², N Ueng-Arporn², P Wongkaewpothong ${ }^{2}$, A Ngamnuan², T Olarnrachin², \\ P Praphanpracha ${ }^{2}$, K Rattanakereepun $^{2}$, N Namwichaisirikul ${ }^{2}$, L Martrakul $^{2}$, V Vanapruek ${ }^{2}$
}

From 2nd International Conference on Prevention and Infection Control (ICPIC 2013)

Geneva, Switzerland. 25-28 June 2013

\section{Introduction}

Medical Parasitology subject is one of basic medical science. We have integrated subject through community based learning.

\section{Objectives}

Assess medical students' attitudes toward practice in laboratory (TC) parasitological examination in the rural community (MPEC).

\section{Methods}

Cross-sectional descriptive study was constructed among 46 medical students during April to July 2012. Attitudes were compared between practice in laboratory (TC) and mobile parasitological examination in the community (MPEC).

\section{Results}

A total of 46 (22 Males and 24 Females) medical students. Most of students was highly satisfied with MPEC. Student' skill, they could be identified parasites during community studied. A total of 85 stool sample was examined and found 7 samples were infected with hookworm (5 patients), Strongyloides stercolaris (1 patient) and Taenia sp. (1 patient), respectively.

\section{Conclusion}

That modification in educational methods. MPEC experience in particular can favorably influence students' attitudes toward basic sciences.

'Pathology, Suranaree University of Technology, Nakhonratchasima, Thailand Full list of author information is available at the end of the article

\section{Disclosure of interest}

None declared.

\section{Author details}

'Pathology, Suranaree University of Technology, Nakhonratchasima, Thailand.

${ }^{2}$ Suranaree University of Technology, Nakhonratchasima, Thailand.

Published: 20 June 2013

doi:10.1186/2047-2994-2-S1-P177

Cite this article as: Kaewpitoon et al:: P177: Community-based learning: medical parasitology in pre-clinical year, Suranaree University of

Technology, Thailand. Antimicrobial Resistance and Infection Control 2013 2(Suppl 1):P177.
Submit your next manuscript to BioMed Central and take full advantage of:

- Convenient online submission

- Thorough peer review

- No space constraints or color figure charges

- Immediate publication on acceptance

- Inclusion in PubMed, CAS, Scopus and Google Scholar

- Research which is freely available for redistribution

Submit your manuscript at www.biomedcentral.com/submit
Ciomed Central

(c) 2013 Kaewpitoon et al; licensee BioMed Central Ltd. This is an Open Access article distributed under the terms of the Creative Commons Attribution License (http://creativecommons.org/licenses/by/2.0), which permits unrestricted use, distribution, and reproduction in any medium, provided the original work is properly cited. 